\title{
Are deep-sea cephalopods really common preys for oceanic seabirds?
}

\author{
Teodoro Vaske Júnior ${ }^{1,2}$ \\ ${ }^{1}$ Laboratório de Elasmobrânquios, Universidade Estadual Paulista - UNESP, \\ Campus do Litoral Paulista, Unidade São Vicente, Praça Infante Dom Henrique, s/n, \\ Parque Bitaru, CEP 11330-900, São Vicente, SP, Brasil \\ ${ }^{2}$ Corresponding author: Teodoro Vaske Júnior, e-mail: vaske@ig.com.br
}

VASKE JR., T. Are deep-sea cephalopods really common preys for oceanic seabirds? Biota Neotrop. 11(1): http://www.biotaneotropica.org.br/v11n1/en/abstract?article+bn02611012011.

\begin{abstract}
An analysis of published data on oceanic seabirds diets, show the predominance of muscular cephalopods with superficial distribution in the oceanic layers, but also important are the gelatinous and ammoniacal species restrict to layers below $300 \mathrm{~m}$ from the surface. In principle, it could be not expected that deep-sea cephalopods are common prey for seabirds like several authors have been concluded. It is proposed in this study that an indirect source, important and easily attainable, have been appeared with the beginning of tuna longline operations. The habit to feed upon viscera of the fishes captured by tuna longliners, that discard the gut contents to the water, may explain the probable equivocal conclusions that deep dwelling cephalopods are natural prey of oceanic seabirds. Keywords: squid, octopus, seabirds, prey-predator.
\end{abstract}

VASKE JR., T. Cefalópodes de profundidade são realmente presas comuns para aves marinhas oceânicas? Biota Neotrop. 11(1): http://www.biotaneotropica.org.br/v11n1/pt/abstract?article+bn02611012011.

Resumo: Uma análise de dados publicados sobre dietas de aves marinhas oceânicas mostra a predominância de cefalópodes musculares e de distribuição mais superficial nas camadas oceânicas, mas também são importantes as espécies gelatinosas e amoniacais restritas a camadas abaixo dos $300 \mathrm{~m}$ da superfície. A princípio, não deveria se esperar que cefalópodes de profundidade fossem considerados presas comuns de aves marinhas oceânicas como reportados por muitos autores. É proposto neste estudo que uma fonte indireta, importante e de fácil obtenção, surgiu com o início das atividades dos barcos atuneiros que operam com espinhel. O hábito de ingerir restos de vísceras de peixes capturados em barcos espinheleiros pode explicar as prováveis conclusões equivocadas de que cefalópodes de profundidade são presas naturais de aves marinhas oceânicas.

Palavras-chave: lula, polvo, aves marinhas, presa-predador. 


\section{Introduction}

Until the beginning of 1980's, the knowledge of the food of albatrosses and petrels was only available from occasional observations of boluses and prey remains observed at colonies (Rodhouse et al. 1987). While the fish and crustaceans in the stomachs are completely digested, mandibles or beaks of cephalopods remain undigested, and can be identified at family or even species level (Clarke et al. 1981). More recent studies show that oceanic cephalopods are reported as a common and natural food item in collections of dietary material of oceanic seabirds like the albatrosses and petrels (Prince 1980, Thomas 1982, Lipinski \& Jackson 1989, Imber 1992, Rodhouse et al. 1987, Weimerskirch \& Wilson 1992, Cooper \& Klages 1995, Croxall 1987, Croxall \& Prince 1994, Cherel \& Klages 1997, van den Hoff 2001, Arata \& Xavier 2003, Xavier et al. 2003, Petry et al. 2007). Cephalopods are also known as the main prey item for several pelagic predators such as tunas, billfishes, oceanic sharks and cetaceans, which reflect the abundance of cephalopods in the epi and mesopelagic environments. However, how albatrosses locate and catch cephalopods is still subject of much debate (Croxall \& Prince 1994, Catry et al. 2004, Weimerskirch et al. 2005).

Croxall \& Prince (1994) suggested that the sources of cephalopods for albatrosses are post-spawning die-offs, fishery waste, vomit of cetaceans, and diel vertical migrants squids. It is suggested in the present study that another important supply of cephalopods, that is profitable for the seabirds, is the remains of the stomach contents of gutted fishes captured by tuna longliners. In this way, the hypothesis of the present study is that an expressive amount of deep dwelling cephalopods ingested by oceanic seabirds derives from tuna longliners, and is not a natural cephalopod prey ingested at the surface. To provide this, a revision of published data on cephalopods found in the diet of oceanic seabirds was compared with data of vertical distribution of cephalopods to explain the differences.

\section{Material and Methods}

Data of oceanic seabirds diet were compiled from literature, where most data are from southern areas of the Atlantic, Indian and Pacific oceans, and also from subantartic waters (Weimerskirch et al. 1993, Croxall \& Prince 1994, 1996, Cooper \& Klages 1995, Cherel \& Klages 1997, Imber 1999, van den Hoff 2001, Cherel et al. 2002, Xavier et al. 2003, Arata \& Xavier 2003, Pitman et al. 2004, Colabuono $\&$ Vooren 2007). References for vertical distribution of cephalopods were obtained from Roper \& Young (1975). Cephalopods which vertical distribution range attains the sea surface where considered as probable natural prey for oceanic seabirds, whereas deep dwelling cephalopods have restricted chances to be preyed by the birds.

\section{Results and Discussion}

The families of cephalopods found in the diet of thirteen species of the oceanic seabirds Wandering (Diomedea exulans), Royal (Diomedea epomophora), Laysan (Phoebastria immutabilis), Waved (Phoebastria irrorata), Black-footed (Phoebastria nigripes), Sooty (Phoebetria fusca), Light-mantled sooty (Phoebetria palpebrata), Black-browed (Thalassarche melanophris), Grey-headed (Thalassarche chrysostoma), Buller's (Thalassarche bulleri), Yellow-nosed (Thalassarche chlororhynchos), and White-chinned petrels (Procellaria aequinoctialis, and Procellaria conspiscillata), are shown in Table 1 . Twenty nine cephalopod families were observed as prey item, where the most frequent were Ommastrephidae, Histioteuthidae, Cranchiidae, Onychoteuthidae, Chiroteuthidae, and Octopoteuthidae. Ommastrephidae was present in all seabirds, and Histioteuthidae was absent only in the Black-footed diet. The vertical distribution of the families indicates that twelve families
$(37.9 \%)$ are deep-water dwellers, i.e., improbable as natural prey for oceanic seabirds.

Scavenging is the main method of food search of seabirds, and then the seabirds are likely suited for daytime foraging. On the other hand, Imber (1992) calculated that $79 \%$ of the cephalopods found in the diet of Wandering albatross could be taken live at the surface, and $95 \%$ of them only or mainly at night, once some species are bioluminescent. Pitman et al. (2004) suggest that Laysan feed mainly on dead rather than live squid, once ommastrephids are their main food item. Moreover, ommastrephids are abundant at the sea surface only at night (Roper \& Young 1975). Grey-headed spent $86-94 \%$ of their nighttime sitting on the sea, once diving is chiefly limited by their visual acuity (Huin \& Prince 1997, Catry et al. 2004).

Post-spawning die-offs are a common event in cephalopods life cycles (Nesis 1982). Muscular squids like epipelagic ommastrephids and onychoteuthids tend to sink when die, while ammoniacal squids like mesopelagic histioteuthids and cranchiids tend to float. According to Croxall \& Prince (1994), the buoyancy of different moribund species of cephalopods could explain the feeding habit on scavenged squid. By far, the most prevalent method of neutral buoyancy in cephalopods is the low-density body fluids resulted from exchange of sodium for ammonium ions (Seibel et al. 2004). High $\mathrm{NH}_{4}^{+}$levels are observed for histioteuthid, cranchiid, chiroteuthid and related squids that are commonly found in the diet of oceanic seabirds.

Wandering albatrosses catch their prey by surface seizing and are ill-adapted for diving (Weimerskirch \& Wilson 1992). Black-browed and Grey-headed albatrosses can dive to $3 \mathrm{~m}$ (Vaske Jr. 1991), $6 \mathrm{~m}$ with a mean maximum depth of 2 to 3 m (Croxall \& Prince 1994, Prince et al. 1994), or $6.5 \mathrm{~m}$ (Huin \& Prince 1997). If we consider the restrict layer that the albatross can penetrate into the water, the feeding strategy must be either target on cephalopods located close to the surface, or forage on an extensive oceanic area looking for moribund or dead squids. Ammoniacal squids have small corporal mass that could be not profitable for seabirds in energetic terms. The wide visual range of the great pelagic fishes that inhabit the same environment of the cephalopods, allow them to prey the moribund cephalopods with much higher efficiency and quickness than the albatrosses. This imply in a probable scarce concentration of moribund squids near the surface that force the albatrosses to increase their foraging effort to zones of predictable prey concentration.

Fishery waste is another important source of cephalopod for seabirds, but fishes have probably much higher importance than cephalopods in trawlers fishery, because the bycatch of trawlers are normally composed of young fishes and non-target organisms of several taxa (Cherel et al. 2002, Arata \& Xavier 2003), except for specific cephalopod fisheries (Thompson 1992). Cephalopods from fishery waste of coastal trawlers are small and coastal species, and are not common in the diet of albatrosses, because albatrosses inhabit the open oceans where bottom trawlers do not operate. For example, Wandering albatrosses spend only $2 \%$ of their time over the shelf, $30 \%$ over slope waters, and $68 \%$ over oceanic waters during foraging (Weimerskirch et al. 2005).

Vomit of cetaceans is proposed as cephalopod source for albatrosses by Clarke et al. (1981), once cephalopods taken from sperm whales (Physeter macrocephalus), long-finned pilot whales (Globicephala melas), and Southern bottlenose whale (Hyperoodon planifrons), are similar to those found in the diet of the Wandering albatross. Nevertheless, vomit of cetaceans may be very occasional, and the spew is probably composed only by beaks, not by muscular cephalopods, if not, vomiting would be prejudicial for the cetacean with the loss of energy supplied by muscular squids. Moreover, cetaceans have scarce distribution around the oceans, which imply that albatrosses must sustain a constant escort to get 
some occasional vomit, which could be not profitable in the energetic point of view.

The species and families of meso and bathypelagic cephalopods found in the diet of albatrosses, like Grimalditeuthidae, Promachoteuthidae, Vampyroteuthidae, Neoteuthidae, Batoteuthidae, Bolitaenidae, Mastigoteuthidae, and Chiroteuthidae, are reported only for catch composition of deep-water research trawls, submergible researches, and also as prey item of tunas, billfishes, oceanic sharks and cetaceans. In this way, these cephalopods of deep waters are probably prey items of great pelagic fishes caught by the longliners, where the hooks are distributed between 30 and $600 \mathrm{~m}$ depths, depending on each longline operation. During the fishing activity guts are discarded to the water, and are ingested by the seabirds that escort the fishing boats. Albatrosses feeding upon guts are easily sighted during longline operations (Vaske Jr. 1991). When a large fish is retrieved and gutted onboard, the fishermen cast away into the water the head, liver, stomach, intestine and gonads. At this moment, albatrosses ingest the viscera floating at the surface or at least three meters deep (Vaske Jr. 1991), including the cephalopods that are deriving from the stomachs of the fishes. In this way, conclusions that deep dwelling cephalopods are natural or common prey of albatrosses and other seabirds may be inadequate, and may lead to equivocal ecological arguments. With the exceptions of some onychoteuthids and architeuthids, the meso and bathypelagic cephalopods have very small body mass, and they are commonly preyed by fishes and cetaceans, so they probably have very low abundance in surface waters.

The lack of good information on albatross feeding habits before the beginning of longline fishing after 1950's do not allow to compare and explain if deep water cephalopods are really common items of the albatrosses, or if the presence of these families are result of a new feeding habit that has appeared with the longline operations. The proportion of cephalopods in the diet represent $40 \%$ in mass for Wandering in South Georgia (Rodhouse et al. 1987), and 77\% in the Crozet islands (Ridoux 1994). For Grey headed, cephalopod proportion is $49 \%$ in South Georgia (Rodhouse et al. 1990) and $89 \%$ in the Crozet islands (Ridoux 1994). In southern Brazil cephalopods represent 32\% of the diet of the Black browed (Petry et al. 2007). Although it is clear the importance of cephalopod as prey items,

Table 1. Families of cephalopods found as prey items of oceanic seabirds compiled from literature. Families in bold are deep dwelling cephalopods.

\begin{tabular}{|c|c|c|c|c|c|c|c|c|c|c|c|c|c|c|c|c|}
\hline & \multirow{2}{*}{ 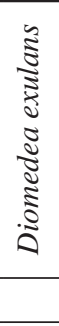 } & \multirow{2}{*}{ 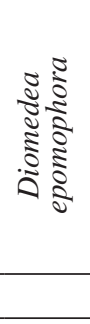 } & \multirow{2}{*}{ 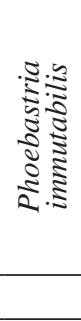 } & \multirow{2}{*}{ 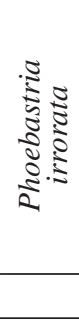 } & \multirow{2}{*}{ 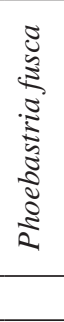 } & \multirow{2}{*}{ 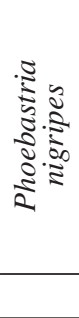 } & \multirow{2}{*}{ 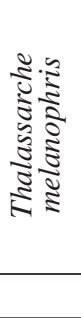 } & \multirow{2}{*}{ 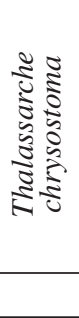 } & \multirow{2}{*}{ 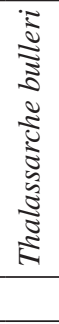 } & \multirow{2}{*}{ 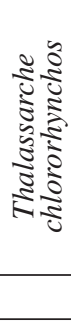 } & \multirow{2}{*}{ 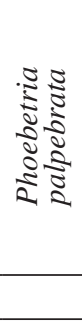 } & \multirow{2}{*}{ 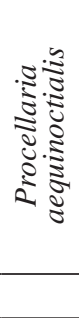 } & \multirow{2}{*}{ 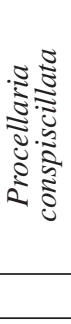 } & & \multicolumn{2}{|c|}{$\begin{array}{c}\text { Depth } \\
\text { distribution } \\
\text { (m) }\end{array}$} \\
\hline & & & & & & & & & & & & & & Min & Med & Max \\
\hline Alloposidae & $\mathrm{X}$ & - & $X$ & - & $X$ & - & - & $X$ & - & - & - & - & - & 0 & 200 & 1000 \\
\hline Ancistrocheiridae & - & - & $X$ & - & - & - & $X$ & - & - & - & - & - & - & 0 & 100 & 1200 \\
\hline Architeuthidae & $\mathrm{X}$ & $X$ & - & - & $\mathrm{X}$ & - & - & $X$ & - & - & - & - & - & 80 & 300 & 1300 \\
\hline Argonautidae & $\mathrm{X}$ & - & - & - & - & - & - & - & $\mathrm{X}$ & - & - & - & - & 0 & 10 & 200 \\
\hline Batoteuthidae & $\mathrm{X}$ & - & - & - & $X$ & - & $X$ & $X$ & - & - & $\mathrm{X}$ & - & - & 300 & 1200 & 2500 \\
\hline Bolitaenidae & - & - & $X$ & - & - & - & - & - & - & - & - & - & - & 200 & 900 & 1200 \\
\hline Brachioteuthidae & $\mathrm{X}$ & - & - & - & $X$ & - & $X$ & $X$ & - & - & - & - & - & 80 & 100 & 200 \\
\hline Chiroteuthidae & $\mathrm{X}$ & - & $X$ & $X$ & $X$ & - & $X$ & $X$ & $\mathrm{X}$ & - & $\mathrm{X}$ & $X$ & - & 100 & 500 & 1200 \\
\hline Cranchiidae & $X$ & $X$ & $X$ & - & $X$ & $X$ & $X$ & $X$ & $\mathrm{X}$ & $X$ & $X$ & - & - & 0 & 300 & 1200 \\
\hline Cycloteuthidae & $\mathrm{X}$ & - & - & - & $\mathrm{X}$ & - & - & $X$ & - & $X$ & $X$ & - & - & 0 & 500 & 1200 \\
\hline Enoploteuthidae & $X$ & - & $X$ & $X$ & $X$ & - & $\mathrm{X}$ & - & $\mathrm{X}$ & $X$ & - & - & - & 0 & 100 & 1200 \\
\hline Gonatidae & $\mathrm{X}$ & - & $X$ & - & $\mathrm{X}$ & - & $\mathrm{X}$ & $X$ & - & $X$ & $X$ & - & - & 0 & 500 & 1200 \\
\hline Grimalditeuthidae & $X$ & - & - & - & - & - & - & - & - & - & - & - & - & 800 & 1500 & 2600 \\
\hline Histioteuthidae & $\mathrm{X}$ & $X$ & $X$ & $X$ & $X$ & - & $X$ & $X$ & $\mathrm{X}$ & $X$ & $\mathrm{X}$ & $X$ & $X$ & 0 & 500 & 1200 \\
\hline Lepidoteuthidae & $X$ & - & $X$ & - & $X$ & - & - & - & - & - & $X$ & - & - & 0 & 500 & 700 \\
\hline Loliginidae & $\mathrm{X}$ & - & - & - & - & - & $X$ & - & - & $X$ & - & - & - & 0 & 20 & 300 \\
\hline Lycoteuthidae & $X$ & - & - & - & $\mathrm{X}$ & - & - & $X$ & - & - & $X$ & - & - & 0 & 300 & 3000 \\
\hline Mastigoteuthidae & $\mathrm{X}$ & - & $X$ & - & $X$ & - & $\mathrm{X}$ & $X$ & $\mathrm{X}$ & - & $\mathrm{X}$ & - & - & 200 & 600 & 1200 \\
\hline Neoteuthidae & $X$ & - & - & - & - & - & - & $X$ & - & - & $\mathrm{X}$ & - & - & 900 & 1500 & 3000 \\
\hline Octopodidae & $\mathrm{X}$ & $\mathrm{X}$ & - & - & - & $X$ & $X$ & - & $\mathrm{X}$ & - & $\mathrm{X}$ & - & - & 0 & 10 & 50 \\
\hline Octopoteuthidae & $X$ & - & $X$ & - & $X$ & $X$ & - & $X$ & $\mathrm{X}$ & $X$ & $X$ & - & $X$ & 0 & 500 & 1200 \\
\hline Ocythoidae & - & - & $X$ & - & - & - & $X$ & $X$ & $\mathrm{X}$ & - & - & $X$ & - & 0 & 10 & 30 \\
\hline Ommastrephidae & $X$ & $X$ & $X$ & $X$ & $X$ & $X$ & $X$ & $X$ & $\mathrm{X}$ & $X$ & $X$ & $X$ & $X$ & 0 & 300 & 1500 \\
\hline Onychoteuthidae & $X$ & $X$ & $X$ & $X$ & $X$ & - & $X$ & $X$ & $X$ & $X$ & $X$ & - & - & 0 & 50 & 500 \\
\hline Pholidoteuthidae & $\mathrm{X}$ & - & - & $X$ & - & - & - & - & - & - & $\mathrm{X}$ & - & - & 0 & 500 & 700 \\
\hline Promachoteuthidae & $\mathrm{X}$ & - & - & - & - & - & - & - & - & - & - & - & - & 1300 & 1500 & 2500 \\
\hline Psychroteuthidae & $\mathrm{X}$ & - & - & - & $\mathrm{X}$ & - & $\mathrm{X}$ & $\mathrm{X}$ & - & - & $\mathrm{X}$ & - & - & 0 & 100 & 200 \\
\hline Sepiidae & $X$ & - & - & - & - & - & - & - & - & - & - & - & - & 0 & 10 & 50 \\
\hline Vampyroteuthidae & $\mathrm{X}$ & - & - & - & - & - & - & - & - & - & - & - & - & 200 & 700 & 1200 \\
\hline
\end{tabular}


further attention is needed in the quantitative point of view, once cephalopod beaks are cumulative in the stomachs, which may lead to an overestimation of the cephalopods in the overall diet, as regarded for pelagic predator such as tunas, billfishes and sharks (Zavala-Camin 1996, Vaske Jr. \& Rincon 1998).

Nowadays, almost whole oceans are explored by longliners, from equatorial to circumpolar waters, which supply with available and abundant food resources through the discharges from the fishing boats, and consequently, an apprenticeship of the seabirds in take advantage of this easy food resource. A tragic consequence that resulted from this apprenticeship was the serious increase of the mortality rate of albatrosses hooked on longlines in the last decades, when the birds eat the baits, normally cephalopods, and die hooked (Brothers 1991, Vaske Jr. 1991, Neves \& Olmos 1997, Neves et al. 2006, Gilman et al. 2007).

As a conclusive remark, it is suggested that cephalopods acquired more importance as a food item of seabirds since the beginning of longliners operations, especially concerned with deep water species that are incorrectly reported as a natural prey item of seabirds, mainly albatrosses.

\section{References}

ARATA, J. \& XAVIER, J.C. 2003. The diet of black-browed albatrosses at Diego Ramirez islands, Chile. Polar Biol. 26:638-647.

BROTHERS, N.P. 1991. Albatross mortality and associated bait loss in the Japanese longline fishery in the Southern Ocean. Biol. Conserv. 55:255-268.

CATRY, P., PHILLIPS, R.A., PHALAN, B., SILK, J.R.D. \& CROXALL, J.P. 2004. Foraging strategies of grey-headed albatrosses Thalassarche chrysostoma: integration of movements, activity and feeding events. Mar. Ecol. Prog. Ser. 280:261-273.

CHEREL, Y. \& KLAGES, N. 1997. A review of the food albatrosses. In Albatross Biology and Conservation. Surrey \& Beatty, Sydney, p.113-136.

CHEREL, Y., WEIMERSKIRCH, H. \& TROUVÉ, C. 2002. Food and feeding ecology of the neritic slope forager black-browed albatross and its relationships with commercial fisheries in Kerguelen waters. Mar. Ecol. Prog. Ser. 207:183-199.

CLARKE, M.R., CROXALL, J.P. \& PRINCE, P.A. 1981. Cephalopod remains in regurgitation of the wandering albatross Diomedea exulans L. at South Georgia. Br. Antarct. Surv. Bull. 54:9-21.

COLABUONO, F.I. \& VOOREN, C.M. 2007. Diet of black-browed Thalassarche melanophrys and Atlantic yellow-nosed T. chlororhynchos albatrosses and white-chinned Procellaria aequinoctialis and sectacled $P$. conspicillata petrels off southern Brazil. Mar. Ornithol. 35:9-20.

COOPER, J.M. \& KLAGES, N.T.W. 1995. The diets and dietary segregation of sooty albatrosses (Phoebetria spp.) in subantarctic Marion Island. Antarct. Sci. 7(1):15-23.

CROXALL, J.P. \& PRINCE, P.A. 1994. Dead or alive: night or day. How do albatrosses catch squid? Antarct. Sci. 6(2):155-162.

CROXALL, J.P. \& PRINCE, P.A. 1996. Cephalopod as prey. I. Seabirds. Phil. Trans. Royal Soc. London Bull. 351:1023-1043.

CROXALL, J.P. 1987. Seabirds feeding biology and role in marine ecosystems. Cambridge.

GILMAN, E., BROTHERS, N. \& KOBAYASHI, D.R. 2007. Comparison of three seabird bycatch avoidance methods in Hawaii-based pelagic longline fisheries. Fish. Sci. 73:208-210.

HUIN, N. \& PRINCE, P.A. 1997. Diving behaviour of the grey-headed albatross. Antarct. Sci. 9(3):243-249.

IMBER, M.J. 1992. Cephalopods eaten by Wandering Albatrosses (Diomedea exulans, L.), breeding at six circumpolar localities. J. Royal Soc. New Zealand. 22:243-263.
IMBER, M.J. 1999. Diet and feeding ecology of the Royal Albatross Diomedea epomophora - king of the shelf break and inner slope. Emu. 99:200-211.

LIPINSKI, M.R. \& JACKSON, A. 1989. Surface-feeding on cephalopods by Procellariiform seabirds in the Southern Benguela Region, South Africa. J. Zool. 218:549-563.

NESIS, K.N. 1982. Cephalopods of the world. V.A.A.P., Moscou.

NEVES, T. \& OLMOS, F. 1997. Albatross mortality in fisheries of the coast of Brazil. In Albatross biology and conservation. Surrey \& Beatty, Sydney, p. 113-136.

NEVES, T., BUGONI, L. \& ROSSI-WONGTSCHOWSKI, C.L.D.B.(ed.). 2006. Aves oceânicas e suas interações com a pesca na região sudestesul do Brasil. Instituto Oceanográfico-USP. Série Documentos Revizee: Score Sul.

PETRY, M.V., FONSECA, V.S.S. \& SCHERER, A.L. 2007. Analysis of stomach contents from the black-browed albatross, Thalassarche melanophris, on the coast of Rio Grande do Sul, Southern Brazil. Polar Biol. 30:321-325.

PITMAN, R.L., WALKER, W.A., EVERETT, W.T. \& GALLO-REYNOSO, J.P. 2004. Population status, foods, and foraging of Laysan albatrosses Phoebastria immutabilis nesting on Guadalupe island, Mexico. Mar. Ornithol. 32:159-165.

PRINCE, P.A. 1980. The food and feeding ecology of grey-headed albatross Diomedea chrysostoma and black-browed albatross D. melanophrys. Ibis. 122:476-488.

PRINCE, P.A., HUIN, N. \& WEIMERSKIRSCH, H. 1994. Diving depths of albatrosses. Antarct. Sci. 6:353-354.

RIDOUX, V. 1994. The diets and dietary segregation of seabirds at the subantartic Crozet islands. Mar. Ornithol. 22:1-192.

RODHOUSE, P.G., CLARKE, M.R. \& MURRAY, A.W.A. 1987. Cephalopod prey of the blackbrowed albatross Diomedea melanophris at the South Georgia. Mar. Biol. 96:1-10.

RODHOUSE, P.G., PRINCE, P.A., CLARKE, M.R. \& MURRAY, A.W.A. 1990. Cephalopod prey of the grey-headed albatross Diomedea chrysostoma. Mar. Biol. 104:353-362.

ROPER, C.F.E. \& YOUNG, R.E. 1975. Vertical distribution of pelagic cephalopods. Smith. Contr. Zool. 209:1-51.

SEIBEL, B.A., GOFFREDI, S.K., THUESEN, E.V., CHILDRESS, J.J. \& ROBISON, B.H. 2004. Ammonium content and buoyancy in midwater cephalopods. J. Exp. Mar. Biol. Ecol. 313:375-387.

THOMAS, G. 1982. The food and feeding ecology of the light-mantled sooty albatross. Emu. 82:92-100.

THOMPSON, K.R. 1992. Quantitative analysis of the use of discards from squid trawlers by black-browed albatrosses Diomedea melanophris in the vicinity of the Falklands islands. Ibis. 134:11-21.

VAN DEN HOFF, J. 2001. Further observations on the cephalopod diet of Wandering Albatrosses (Diomedea exulans L.) at Macquire Island. Emu. 101:169-172.

VASKE Jr., T. \& RINCÓN, G. 1998. Conteúdo estomacal dos tubarões azul (Prionace glauca) e anequim (Isurus oxyrhincus) em águas oceânicas no sul do Brasil. Rev. Bras. Biol. 58(3):443-450.

VASKE Jr., T. 1991. Seabirds mortality on longline fishing for tuna in southern Brazil. Cien. Cult. 43(5):388-390.

WEIMERSKIRCH, H. \& WILSON, R.P. 1992. When do wandering albatrosses Diomedea exulans forage? Mar. Ecol. Prog. Ser. 86:297-300.

WEIMERSKIRCH, H., GAULT, A. \& CHEREL, Y. 2005. Prey distribution and patchiness: factors in foraging success and efficiency of wandering albatrosses. Ecology 86(10):2611-2622.

WEIMERSKIRCH, H., SALAMOLARD, M., SARRAZIN, F., JOUVENTIN, P. 1993. Foraging strategy of wandering albatrosses through the breeding season: a study using satellite telemetry. Auk. 110:325-342.

XAVIER, J.C., CROXALL, J.P., TRATHAM, P.N. \& WOOD, A.G. 2003. Feeding strategies and diet of breeding grey-headed and wandering albatrosses at South Georgia. Mar. Biol. 143:221-232.

ZAVALA-CAMIN, L.A. 1996. Introdução aos estudos sobre alimentação natural em peixes. EDUEM , Maringá. 